ARCHIWA - KANCELARIE - ZBIORY

NR $4(6) / 2013$

ANDRZEJ WAŁKówsKi

Uniwersytet Łódzki

\title{
MOJE WSPOMNIENIE \\ o Profesorze WacŁawie Korcie
}

Słowa kluczowe: Wacław Korta; Andrzej Wałkówski

Ke y w o rd s: Wacław Korta; Andrzej Wałkówski

Abstract

Wacław Korta życie zawodowe związał z Uniwersytetem Wrocławskim. Jego zainteresowania badawcze koncentrowały się na górze Ślęży, historii społeczno-gospodarczej średniowiecza, dziejopisarstwie oraz naukach pomocniczych historii, a przede wszystkim na dyplomatyce. Działał na polu edytorstwa. Pod koniec życia zajął się przygotowaniem syntezy dziejów Śląska do schyłku XVIII w., którą wydano pośmiertnie. Własnymi zainteresowaniami naukowymi umiał twórczo „zarazič" swoich uczniów. Poświęcenie się studiom nad dokumentem pozwalało uczniom Prof. Korty zdobyć przygotowanie erudycyjne. Wysokie wymagania nie ograniczały się tylko do samego warsztatu. Profesor starał się, aby tematy były nowatorskie i wnoszące twórcze ustalenia.

Niniejszy tekst nie pretenduje do miana artykułu czy referatu. Nie nadałem mu bowiem charakteru naukowego. Nie jest on nawet, poza szczególnymi wyjątkami, „opancerzony osłoną przypisów”. Stanowi jedynie parę osobistych wspomnień i refleksji, które nie są wolne od subiektywnych odczuć. 


\section{ANDRZEJ WAŁKówsKi}

Profesora Wacława Kortę poznałem na początku roku 1980. Uzyskawszy w trakcie sesji zimowej wysoką średnią, chciałem studiować tokiem indywidualnym, a ponieważ zainteresowania moje koncentrowały się na naukach pomocniczych, w grę wchodziła opieka naukowa Profesora. Od tego czasu związałem się z Jego osobą, aż do roku 1999, roku Jego śmierci. Był On nie tylko promotorem mojej pracy magisterskiej, ale także doktoratu, a ponadto konsultował pewne fragmenty pracy habilitacyjnej.

Kim był ten niezwykły człowiek, z którym przyszło mi współpracować blisko 20 lat? Pochodził On z rodziny chłopskiej - urodził się 26 sierpnia 1919 roku w Woli Nieszkowskiej, koło Bochni. Nie były to czasy, kiedy osoba pochodzenia chłopskiego miała łatwy start w zakresie wyższego wykształcenia, ale pracowitość i sumienność, cechujące przez całe życie Profesora, pozwoliły mu na pokonanie trudności. Od 1934 roku, po ukończeniu szkoły podstawowej, kontynuował edukację w Państwowym Gimnazjum oraz Liceum im. Kazimierza Wielkiego, w Bochni. Wybuch wojny w 1939 roku przerwał naukę, a Profesor, jako prawdziwy patriota, włączył się do ruchu oporu. Był żołnierzem AK na terenie powiatu bocheńskiego. Jego zasługi wojenne znalazły swoje odbicie w licznych odznaczeniach, z których wymienię tylko niektóre: Brązowy Krzyż Zastugi z Mieczami (1945) i Krzyż Partyzancki (1972). Po wojnie Profesor zdał maturę i od roku 1945 studiował historię z archeologią na UJ1. Wybór tych dwóch kierunków miał zaowocować cennymi badaniami, które wyświetliły tajemnice „śląskiego Olimpu” - góry Ślęży². Śląsk, wszechobecny w badaniach Profesora Wacława Korty, stał się skutecznym magnesem - od 1946 kontynuował On studia we Wrocławiu, by w 1951 roku ukończyć je ze stopniem magistra. Jednak od 1950, jako student, został zatrudniony w charakterze młodszego asystenta w Katedrze Historii Polski Średniowiecznej, pod opieką sławnego już przed wojną Karola Maleczyńskiego. Z Uniwersytetem Wrocławskim związał całe swoje zawodowe życie, aż do początku lat 90. XX wieku, kiedy to odszedł na emeryturę. W roku 1960 obronił doktorat, poświęcony rozwojowi wielkiej własności na Śląsku do połowy XIII wieku. Natomiast colloquium habilitacyjne odbyło się w roku 1966 na podstawie pracy Średniowieczna annalistyka ślaska, która zaliczana jest do

${ }^{1}$ K. Bobowski, Profesor Wactaw Korta jako cztowiek i jako uczony, [w:] Źródtoznawstwo i studia historyczne. Ksiega Jubileuszowa Prof. dr. hab. Wactawa Korty, red. K. Bobowski, Wrocław 1989, s. 11.

2 W. Korta, Tajemnice góry Ślęży, Katowice 1988. 
klasyki historiografii polskiej. W roku 1968 otrzymał kierownictwo Zakładu Nauk Pomocniczych Historii i Archiwistyki. Obowiązki kierownika zakładu pełnił aż do odejścia na emeryturę. W 1977 roku od Rady Państwa otrzymał tytuł profesora ${ }^{3}$.

Główne kierunki zainteresowań naukowych Profesora Wacława Korty koncentrowały się na wspomnianej już górze Ślęży, w czym łączył przygotowanie historyka i archeologa, na historii społeczno-gospodarczej średniowiecza (studia nad wielką własnością feudalną na Śląsku), dziejopisarstwie (studia nad annalistyką śląską) oraz naukach pomocniczych historii ${ }^{4}$, rozumianych przede wszystkim jako dyplomatyka. Ponadto działał na polu edytorstwa ${ }^{5}$ wydając regesty średniowiecznych dokumentów śląskich ${ }^{6}$. Pod koniec życia zajął się przygotowaniem syntezy dziejów Śląska do schyłku XVIII wieku, którą wydano pośmiertnie ${ }^{7}$. Własnymi zainteresowaniami naukowymi umiał twórczo „zarazić” swoich uczniów. Jako przykład mogą posłużyć badania nad Ślężą, które wiążą się z początkami kanoników regularnych na Śląsku. W tym zakresie aktywizowała się Anna Pobóg-Lenartowicz, obecnie profesor zwyczajny Uniwersytetu Opolskiego, która m.in. opracowała trzy książki poświęcone temu zakonowi, zaczynając od jego ślężańskiego epizodu ${ }^{8}$. Hołdowanie dyplomatyce w zakresie nauk pomocniczych było - zdaniem Profesora - uzasadnione tym, że nauka ta wiązała ze sobą inne dyscypliny - paleografię, sfragistykę, archiwistykę, ale także genealogię i toponomastykę. W przypadku obecności herbu na pieczęci dochodziła także heraldyka.

Takim też torem toczyła się moja prawie dwudziestoletnia współpraca z Mistrzem. Jako student drugiego roku historii, uzyskawszy tzw. Indywidualny Tok Studiów, zacząłem pod Jego kierunkiem studia nad paleografią, polegające na odczytywaniu i tłumaczeniu na polski tablic paleograficznych, zawierających fotokopie śląskich dokumentów. Była to wyższa szkoła jazdy nie tylko ze względu na wymagania, ale i „uzbrojenie” warsztatu w specjalistyczne słowniki brachygraficzne oraz łacińsko-polskie itp. Odczytywanie i tłu-

${ }^{3}$ K. Bobowski, dz. cyt., s. 11-12.

4 Tamże, s. 13.

5 Tamże.

${ }^{6}$ Regesty Ślaskie, t. I-V, red. W. Korta, Wrocław-Warszawa 1975-1992.

7 W. Korta, Historia Ślaska do 1763 roku, Warszawa 2003.

8 A. Pobóg-Lenartowicz, Uposażenie i dziatalność gospodarcza klasztoru kanoników regularnych we Wroctawiu, Opole 1994; tejże, Kanonicy regularni na Ślasku, Opole 1999; tejże, Konwent kanoników regularnych NMP na Piasku we Wroctawiu, Opole 2007. 
maczenie dokumentu stanowiło przy tym tylko wstęp do przygotowania jego opracowania ewidencyjnego w archiwum (obecność archiwistyki) z możliwie obszernym regestem. To ostatnie było wprawką do edytorstwa (Profesor wydawał drukiem regesty dokumentów śląskich). Edytorska wprawka nie ograniczała się tylko do regestowania. Trzeba było wykonać wszystkie czynności przygotowujące tekst do wydania drukiem w wersji oryginalnej i tłumaczonej. Tego typu szkolenie trwało w moim przypadku pół roku. Po tym okresie przeszedłem do pisania pracy magisterskiej. Jej podstawą był najstarszy kopiarz lubiąski, pochodzący z połowy XIII wieku, najstarszy tego typu zabytek zachowany w Polsce. Zadanie, jakie otrzymałem, było w pewnym sensie kontynuacją mojego poprzedniego, półrocznego przygotowania. Zasadą szkoły mojego Mistrza była bowiem ciągłość i kontynuacja, która zapewniała zarówno wysoki poziom, jak i pozwalała zawsze na ostateczne, w pełni dopracowane zakończenie każdego zadania. Miałem odczytać, przetłumaczyć i opracować w/w kodeks. Wykonanie tegoż zadania dało mi nie tylko stopień magistra, ale także przyniosło sporą satysfakcję, jaką było wydanie trzech artykułów za życia Profesora i jednego po Jego śmierci ${ }^{9}$. Wyniki należy uznać za wartościowe dla nauki, ponieważ praca ta otrzymała trzecią nagrodę $\mathrm{Na}$ czelnego Dyrektora Archiwów Państwowych z okazji VI Tygodnia Archiwów w 1984 roku. Jak widać, Profesor Wacław Korta powierzał zadania wiele wymagające od swoich uczniów, ale dające im możliwość wykazania się, zapewniające satysfakcję, publikacje drukiem, a przede wszystkim służące postępowi nauki.

Praca doktorska miała wykorzystać moje doświadczenia zdobyte podczas pisania pracy magisterskiej, ale nie mogła nawet pod względem metodologicznym stanowić jej powielenia. Chodziło o to, że temat nie powinien być do niej podobny. Musiał on stanowić inny rodzaj opracowania. Miało to na celu nauczenie doktoranta nowych metod, a ponadto ułatwiało wybór takiego tematu, który był nowatorski. Dzięki temu praca doktorska służyła nie tylko zdobyciu stopnia, ale także rozwojowi polskiej nauki historycznej. Oczywi-

9 A. Wałkówski, Najstarszy kopiarz lubiąski, Acta Universitatis Wratislaviensis, No 800, Historia t. 50, 1985, s. 163-221; tenże, $Z$ badań nad najstarszym kopiarzem lubiąskim, [w:] Historia i kultura cystersów w dawnej Polsce i ich europejskie związki, red. J. Strzelczyk, Poznań 1987, s. 445-452; tenże, Transumowanie ogólnocysterskich bulli papieskich 27 I 1234 - wrzesień 1234 w świetle najstarszego kopiarza lubiąskiego, [w:] Źródłoznawstwo i studia historyczne..., s. 115-121; tenże, Echa byszewskie w najstarszym kopiarzu lubiąskim, „Nasza Przeszłość”, t. 96, 2001, s. 111-123. 
ście możliwe i pożądane było wykorzystywanie wcześniejszych doświadczeń. W moim przypadku oznaczało to wybór tematu dotyczącego kancelarii książąt legnickich do końca XIII wieku. W zasadzie były to dwie kancelarie Bolesława II Rogatki oraz Henryka V Grubego. Mogłem wykorzystać swoje doświadczenia z zakresu paleografii, jakie zdobyłem w przypadku pracy magisterskiej nad najstarszym kopiarzem lubiąskim. Zarazem jednak musiałem wejść w szeroko rozumianą analizę formularza i dyktatu dyplomów książęcych oraz posiąść umiejętność rozpoznawania na tej podstawie ich proweniencji kancelaryjnej. Ponadto potrzebne były wiadomości w zakresie sfragistyki (pieczęcie). Trzeba było także umieć powiązać wyniki tych badań z dziejami polityki książąt legnickich - np. należało wyjaśnić, dlaczego w danym okresie rośnie albo spada liczba dokumentów, które zostały sporządzone w kancelarii książęcej. Zadanie to również dało mi satysfakcję, a jego wynikiem były dwie książki, poświęcone osobno kancelarii Bolesława II Rogatki i Henryka V Grubego, wydane w tym samym 1991 roku $^{10}$ - ewenement jak na pracę doktorską. Do tego należy dodać dwa artykuły (jeden opublikowany w Niemczech) ${ }^{11}$. Nie da się zaprzeczyć, że powierzenie opracowania na jeden doktorat dwóch, jak się okazało, odrębnych kancelarii należało do ponadprzeciętnych wymagań. Jednak wysiłek opłacił się w postaci nie tylko publikacji, ale otworzył dla mnie nowy kierunek zainteresowań, jakim były dzieje Ziemi Lubuskiej. W trakcie rozważań nad dokumentami Rogatki prowadziłem badania w zakresie tła politycznego i kancelaryjnego wystawienia sławnego, lubuskiego dokumentu tegoż księcia z 1249 roku $^{12}$. Wyniki miałem okazję zaprezentować na lokalnych sesjach naukowych, zwanych Colloquiami Lubuskimi. Dało to impuls dalszym badaniom, dotyczącym dziejów biskupstwa w Lubuszu, które kontynuuję do dzisiaj ${ }^{13}$. Jak widać, Profesor Wacław

10 Tenże, Dokumenty i kancelaria księcia Bolestawa II Rogatki, Zielona Góra 1991; tenże, Dokumenty i kancelaria księcia legnickiego Henryka V Grubego, Wrocław 1991.

11 Tenże, Umowa księcia Bolestawa II Rogatki z arcybiskupem magdeburskim Wilbrandem z 20 IV 1249 roku, [w:] Studia Zachodnie, red. J. Benyskiewicz, Zielona Góra 1992, s. 25-35; tenże, Urkunden und Kanzlei Heinrichs V. (des Dicken). Eine Ergänzung, „Jahrbuch der Schlesischen Friedrich - Wilhelms - Universtät zu Breslau”, t. 35, 1994, s. $33-45$.

12 Tenże, Umowa księcia Bolestawa II Rogatki..., s. 25-35.

13 Tenże, Czy biskup lubuski Wawrzyniec byt mnichem lubiąskim? Próba odpowiedzi na podstawie analizy jego dokumentów, [w:], Colloquia Lubuskie. Z dyplomatyki i heraldyki dawnego biskupstwa lubuskiego, oprac. M. Golemski, Zielona Góra-Gorzów Wielkopolski 1994, s. 21-71; tenże, Czy diecezja lubuska rządzito w latach 1201-1233 dwóch 
Korta umiał tak dobierać tematy prac, aby jego uczniowie mogli poznawać nowe obszary badawcze i rozwinąć własne, oryginalne zainteresowania.

W tym kierunku szły nasze dyskusje dotyczące mojego tematu habilitacyjnego. W ich wyniku zdecydowałem się na opracowanie skryptoriów dolnośląskich cystersów do końca XIII wieku. Profesor zaakceptował mój pomysł, ponieważ uważał, że jako przyszły, samodzielny pracownik naukowy powinienem mieć własny i oryginalny obszar badawczy, w którym mógłbym się na tyle wykazać, aby stać się rozpoznawalnym badaczem. Faktycznie, nikt wcześniej nie podjął się opracowania skryptoriów jakiegokolwiek zakonu, obejmując jego całą, terytorialną gałąź filiacyjną w dłuższym czasie, a przy tym ujmując kompleksowo ogół jej dorobku piśmienniczego. Trzeba przy tym dodać, że nawet po opublikowaniu mojej książki habilitacyjnej jak dotąd nikt nie podjął się analogicznego tematu. Nic dziwnego, ponieważ był on nie tylko nowatorski, ale i bardzo trudny. Mnie udało się to dlatego, że zawsze mogłem liczyć na życzliwą radę Profesora i jego wsparcie w trudnych chwilach. Efektem tego była nie tylko udana habilitacja, ale też wartościowe opracowanie naukowe ${ }^{14}$, o czym świadczy przyznana w połowie 1999 roku nagroda Ministra Edukacji Narodowej. Niestety, Mistrz nie dożył już tej chwili - zmarł kilka miesięcy wcześniej.

Reasumując, szkoła nauk pomocniczych Profesora Wacław Korty w centrum swoich zainteresowań postawiła średniowieczny dokument. Zabieg ten okazał się słuszny, ponieważ źródło to skupiało na sobie nie tylko uwagę dyplomatyki, ale także paleografii, sfragistyki, archiwistyki i innych nauk pomocniczych. Poświęcenie się studiom nad dokumentem pozwalało uczniom Profesora zdobyć maksymalne przygotowanie erudycyjne. Jednocześnie wysokie wymagania nie ograniczały się tylko do samego warsztatu. Profesor starał się, aby tematy były nowatorskie i wnoszące twórcze ustalenia. Korzystała na tym polska nauka historyczna, korzystali na tym Jego uczniowie. Opracowanie pod kierunkiem Profesora pracy magisterskiej, doktorskiej czy konsultowanej przez niego pracy habilitacyjnej przynosiło efekty w postaci publikacji, nagród oraz oznaczało wysoką pozycję w świecie naukowym. Otwierało

biskupów o imieniu Wawrzyniec?, „Nadwarciański Rocznik Historyczno-Archiwalny”, nr 2, 1995, s. 31-40; tenże, Wawrzyniec biskup lubuski. Szkic biograficzny, „Studia Paradyskie", t. 14, 2004, s. 203-229.

${ }_{14}$ Tenże, Skryptoria cystersów filiacji portyjskiej na Ślasku do końca XIII wieku, Zielona Góra-Wrocław 1996. 
nowe, własne obszary badawcze. Świadczą tym słowa innego, wielkiego znawcy nauk pomocniczych historii, Profesora Aleksandra Gieysztora. Na zakończenie mojego colloquium habilitacyjnego powiedział: Panie Profesorze - stworzyt Pan wtasna szkotę! Nic dodać, nic ująć.

\section{Bibliografia}

Bobowski K., Profesor Wactaw Korta jako cztowiek i jako uczony, [w:] Źródłoznawstwo i studia historyczne. Księga Jubileuszowa Prof. dr. hab. Wacława Korty, red. K. Bobowski, Wrocław 1989.

Korta W., Historia Ślaska do 1763 roku, Warszawa 2003.

Korta W., Tajemnice góry Ślęży, Katowice 1988.

Pobóg-Lenartowicz A., Kanonicy regularni na Ślasku, Opole 1999.

Pobóg-Lenartowicz A., Konwent kanoników regularnych NMP na Piasku we Wroctawiu, Opole 2007.

Pobóg-Lenartowicz A., Uposażenie i dziatalność gospodarcza klasztoru kanoników regularnych we Wroctawiu, Opole 1994.

Regesty Ślaskie, t. I-V, red. W. Korta, Wrocław-Warszawa 1975-1992.

Wałkówski A., Czy biskup lubuski Wawrzyniec byt mnichem lubiaskim? Próba odpowiedzi na podstawie analizy jego dokumentów, [w:] Colloquia Lubuskie. Z dyplomatyki i heraldyki dawnego biskupstwa lubuskiego, oprac. M. Golemski, Zielona Góra-Gorzów Wielkopolski 1994.

Wałkówski A., Czy diecezją lubuską rządzito w latach 1201-1233 dwóch biskupów o imieniu Wawrzyniec?, „Nadwarciański Rocznik Historyczno-Archiwalny”, nr 2, 1995.

Wałkówski A., Dokumenty i kancelaria księcia Bolestawa II Rogatki, Zielona Góra 1991.

Wałkówski A., Dokumenty i kancelaria księcia legnickiego Henryka V Grubego, Wrocław 1991.

Wałkówski A., Echa byszewskie w najstarszym kopiarzu lubiąskim, „Nasza Przeszłość”, t. 96, 2001.

Wałkówski A., Najstarszy kopiarz lubiąski, „Acta Universitatis Wratislaviensis”, No 800, Historia t. 50, 1985,

Wałkówski A., Skryptoria cystersów filiacji portyjskiej na Ślasku do końca XIII wieku, Zielona Góra-Wroctaw 1996.

Wałkówski A.,Transumowanie ogólnocysterskich bulli papieskich 27 I 1234 - wrzesień 1234 w świetle najstarszego kopiarza lubiąskiego, [w:] Źródłoznawstwo i studia historyczne. Księga Jubileuszowa Prof. dr. hab. Wacława Korty, red. K. Bobowski, Wrocław 1989.

Wałkówski A., Umowa księcia Bolestawa II Rogatki z arcybiskupem magdeburskim Wilbrandem z 20 IV 1249 roku, [w:] Studia Zachodnie, red. J. Benyskiewicz, Zielona Góra 1992. 


\section{AndRZEJ WaŁKówsKi}

Wałkówski A., Urkunden und Kanzlei Heinrichs V. (des Dicken). Eine Ergänzung, „Jahrbuch der Schlesischen Friedrich-Wilhelms-Universtät zu Breslau”, t. 35, 1994.

Wałkówski A., Wawrzyniec biskup lubuski. Szkic biograficzny, „Studia Paradyskie”, t. 14, 2004

Wałkówski A., Z badań nad najstarszym kopiarzem lubiaskim, [w:] Historia i kultura cystersów w dawnej Polsce i ich europejskie zwiąki, red. J. Strzelczyk, Poznań 1987.

\section{Su m mary}

My recollection of Professor Waclaw Korta

Waclaw Korta bound his professional life to the Wroclaw University. His research interests centered on the Sleza Mountain, the socio-economic history of the Middle Ages, historiography, the auxiliary sciences in historical research, and, above all, diplomatics. He also did editing work. In his twilight years, he took on preparing a synthesis of the history of Silesia to the end of the $18^{\text {th }}$ century, which was published posthumously. He possessed the ability to "infect" his students with his science interests. Comitting oneself to studying the documents, allowed Korta's students to develop their erudition. The demand for high quality work was not confined to the methods of work. The Professor endeavoured for the dissertartions' topics to be innovative and to bring creative findings. 